\title{
Effects of Oxygen Concentration on Biomass Production, Maximum Specific Growth Rate and Extracellular Enzyme Production by Three Species of Cutaneous Propionibacteria Grown in Continuous Culture
}

\author{
By J. H. COVE, ${ }^{1} \dagger$ K. T. HOLLAND ${ }^{1 *}$ AND W. J. CUNLIFFE ${ }^{2}$ \\ ${ }^{1}$ Department of Microbiology, University of Leeds, Leeds LS2 9JT, U.K. \\ ${ }^{2}$ Department of Dermatology, The General Infirmary and St. James' (University) Hospital, \\ Leeds LSI 3EX, U.K.
}

(Received 7 February 1983; revised 13 May 1983)

Propionibacterium acnes, Propionibacterium avidum and Propionibacterium granulosum were grown in continuous culture at $0-100 \%$ air saturation using a semi-synthetic medium. Maximum specific growth rate, biomass concentration and extracellular lipase, hyaluronate lyase and phosphatase activities were determined. All three species were capable of growth at $100 \%$ air saturation but at reduced growth rates. The presence of oxygen altered the production of extracellular enzymes. Propionibacterium avidum was the best adapted for growth in aerobic environments.

\section{INTRODUCTION}

Propionibacterium acnes constitutes the major fraction of the microflora in areas of adult human skin rich in sebaceous glands, i.e. face, back and chest (Johnson \& Cummins, 1972; McGinley et al., 1978). Propionibacterium granulosum and Propionibacterium avidum are isolated from these areas in lesser numbers (McGinley et al., 1978). Propionibacterium avidum also colonizes skin of high humidity, i.e. axilla and groin (McGinley et al., 1978). Propionibacteria can be isolated both from the skin surface and from the pilosebaceous ducts (Puhvel et al., 1975). They produce a variety of extracellular enzymes including lipase (Hassing, 1971; Kellum et al., 1970; Ingham et al., 1981; Greenman et al., 1981), hyaluronidase (hyaluronidase lyase) (Puhvel \& Reisner, 1972; Ingham et al., 1979; Greenman et al., 1981), protease and DNAase (Marples \& McGinley, 1974) and acid phosphatase (Ingham et al., 1980; Greenman et al., 1981). Holland et al. (1978) suggested that altered conditions in the pilosebaceous duct, i.e. pH or oxygen concentration, effect changes in the physiology of the resident bacteria and in the synthesis of extracellular products.

The cutaneous propionibacteria are generally regarded as anaerobes since they normally require anaerobiosis for their isolation and growth (Evans et al., 1950). However, these bacteria can also be isolated aerobically (Evans \& Mattern, 1979). It is also likely that they are exposed to oxygen in their natural environment due to diffusion both from the tissues and the atmosphere. The aim of this study was to determine the effects of oxygen on the growth and production of extracellular enzymes by cutaneous propionibacteria.

\section{METHODS}

Organism and media. Propionibacterium acnes (laboratory strain P37), P. avidum [laboratory strain PF77 (i)] and $P$. granulosum [laboratory strain PF208 (ii)] were originally isolated from patients attending the Dermatology clinic at Leeds General Infirmary and were typed according to the scheme of Marples \& McGinley (1974). The strains were maintained at $-196^{\circ} \mathrm{C}$ under liquid nitrogen. The growth medium was that used by Eaves et al. (1979).

† Present address: Glaxo Group Research Ltd, Biotechnology Department, Microbiology Division, Greenford Road, Greenford, Middlesex UB6 0HE, U.K. 
Table 1. Dilution rates used to determine $\mu_{\max }$ by the washout method

\begin{tabular}{cccc}
$\begin{array}{c}\text { Oxygen concn } \\
\text { (\% air saturation) }\end{array}$ & \multicolumn{3}{c}{ Dilution rate $\left(\mathrm{h}^{-1}\right)$} \\
\hline 0 & 0.32 & 0.40 & 0.40 \\
10 & 0.17 & 0.25 & 0.23 \\
20 & 0.09 & 0.23 & 0.26 \\
40 & 0.16 & 0.24 & 0.19 \\
60 & 0.17 & 0.24 & 0.19 \\
80 & 0.11 & 0.22 & 0.20 \\
100 & 0.16 & 0.18 & 0.13
\end{tabular}

The medium used for the growth of $P$. gramulosum contained glucose $\left(2 \mathrm{~g}^{-1}\right)$, since this species has been shown to require a carbohydrate carbon source (Holland et al., 1979; Greenman et al., 1981). The medium was autoclaved at $121^{\circ} \mathrm{C}$ for $80 \mathrm{~min}$ in 201 amounts; the vitamins, mineral salts and glucose $(10 \%, \mathrm{w} / \mathrm{v})$ were autoclaved separately at $121^{\circ} \mathrm{C}$ for $15 \mathrm{~min}$, cooled and added aseptically to the rest of the medium.

Continuous culture apparatus and conditions. Organisms were grown in a 1 litre culture vessel (working volume $750 \mathrm{ml}$ ) with control modules for temperature, stirrer, gas flow, $\mathrm{pH}$ and dissolved oxygen concentration (Series 500, LH Engineering, Stoke Poges, Bucks., U.K.). The cultures were maintained at $37^{\circ} \mathrm{C}$ and at pH 5.7 by the automatic addition of $2 \mathrm{M}-\mathrm{NaOH}$ or $2 \mathrm{M}-\mathrm{HCl}$, and were stirred at 500 r.p.m. Percentage oxygen saturation in the culture was measured using a galvanic oxygen electrode supplied by L. H. Engineering, Stoke Poges, Bucks., U.K. The electrode was calibrated at zero and $100 \%$ saturation by sparging oxygen-free nitrogen at $100 \mathrm{ml} \mathrm{min}^{-1}$ and air at $300 \mathrm{ml} \mathrm{min}^{-1}$, respectively. Hence, $100 \%$ saturation in the culture is with reference to the partial pressure of oxygen in air. The oxygen saturation in the culture was controlled automatically using a gas mixture of oxygen-free nitrogen and air. The pH and oxygen saturation were chart recorded (Foster Cambridge Ltd). Foaming was controlled by the addition of polypropylene glycol antifoam $(\mathrm{BDH})$ where necessary. The dilution rates were maintained at one-third of the maximum specific growth rate of the organism under the conditions imposed. Samples were taken at regular intervals for microscopical examination and for plating on to Reinforced Clostridial Medium (Oxoid), which was incubated anaerobically in $\mathrm{H}_{2}: \mathrm{CO}_{2}(95: 5, \mathrm{v} / \mathrm{v})$ at $37^{\circ} \mathrm{C}$ for $5 \mathrm{~d}$, and on $5 \%(\mathrm{w} / \mathrm{v})$ heated horse blood agar (Oxoid), which was incubated aerobically for $2 \mathrm{~d}$ at $37^{\circ} \mathrm{C}$, to test for purity.

Determination of biomass and maximum specific growth rates. Bacterial dry weight was used as a measure of the biomass and was determined by the method of Greenman et al. (1981). The absorbance at $540 \mathrm{~nm}$ was used to measure bacterial concentration for determination of maximum specific growth rate. The maximum specific growth rate $\left(\mu_{\max }\right)$ was determined by the 'washout method' of Tempest (1970). The dilution rate was raised to near $\mu_{\max } 48 \mathrm{~h}$ before it was raised above $\mu_{\max }$. The values of $D$ above $\mu_{\max }$ are given in Table 1 .

Total and viable bacterial counts. Total counts were measured using a Helber counting chamber and phasecontrast microscopy and viable counts were determined using conventional plating techniques.

Extracellular protein. Protein in the medium was determined by the method of Bradford (1976) using the procedure and reagents described in the Bio-Rad Laboratories technical bulletin 1051E. The results were expressed as bovine serum albumin $\left(\mathrm{g} \mathrm{l}^{-1}\right)$ equivalent and the production rate of extracellular protein was calculated as $\mathrm{g}^{-1} \mathrm{~h}^{-1}$.

Extracellular enzymes. Lipase (EC 3.1.1.3), hyaluronate lyase (EC 4.2.2.1) and acid phosphatase (EC 3.1.3.2) activities were assayed by the methods used by Holland et al. (1979). Enzyme units of activity were expressed as $\mu \mathrm{mol}$ end product produced $\min ^{-1}$ as follows: lipase, $\mu \mathrm{mol}$ oleic acid $\min ^{-1}$; hyaluronidase, $\mu$ mol $N$-acetylglucosamine $\min ^{-1}$ and phosphatase $\mu \mathrm{mol} p$-nitrophenol $\mathrm{min}^{-1}$. The production rates of extracellular enzymes were expressed as units of activity (g biomass) $)^{-1} \mathrm{~h}^{-1}$ (Pirt, 1975).

Stability of extracellular enzymes. The stability of extracellular enzymes was determined anaerobically and at $100 \%$ air saturation using the method described by Eaves et al. (1979). The production rates were corrected for loss of enzyme activity due to instability using the formula:

$$
\text { corrected activity }=[(\lambda+D) / D] \times \text { measured activity }
$$

where $D$ is the dilution rate and $\lambda$ is the denaturation constant for the enzyme (Eaves et al., 1979).

Glucose. The glucose concentration in cultures of $P$. granulosum was determined according to Sigma technical bulletin no. 510 .

Phosphorus. Inorganic phosphate in the medium was determined according to Sigma technical bulletin no. 670 .

$\mathrm{N}$-acetylglucosamine. Culture supernatant fluids were assayed for $\mathrm{N}$-acetylglucosamine using the colorimetric assay of Reissig et al. (1955).

Steady state. Biomass and extracellular enzyme activities were determined on samples taken from the chemostat 


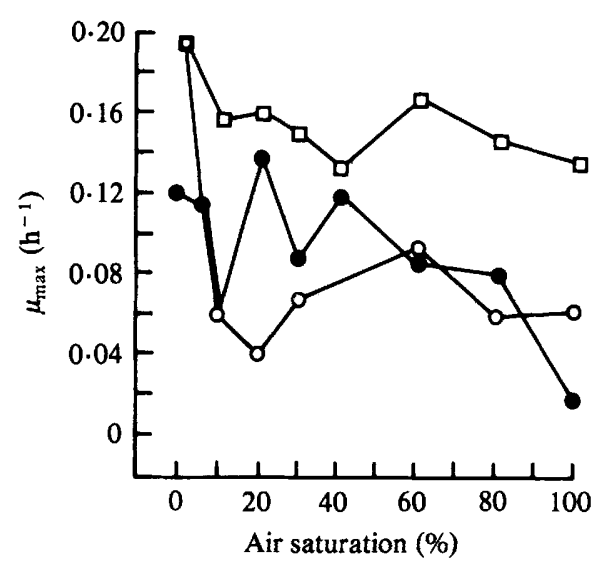

Fig. 1

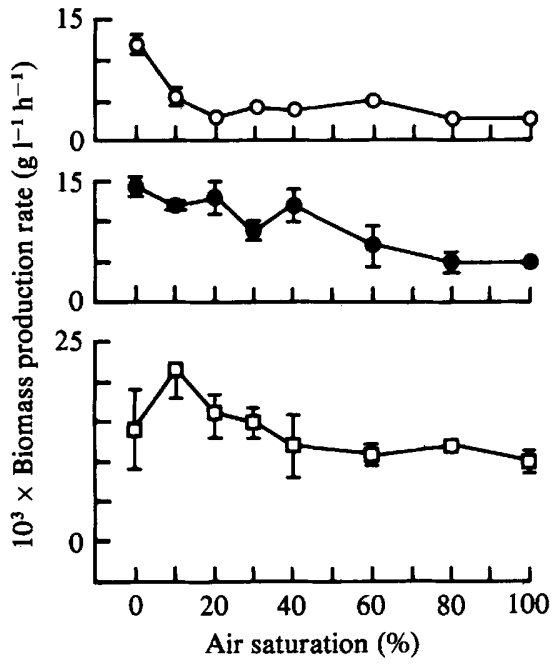

Fig. 2

Fig. 1. Effect of oxygen concentration on the maximum specific growth rate of $P$. acnes (O), $P$. granulosum (O) and $P$, avidum $(\square)$.

Fig. 2. Effect of oxygen concentration on biomass production rate at $0.33 \mu_{\max }$ of $P$. acnes (O), $P$. granulosum (O) and $P$. avidum $(\square)$. Biomass production rate is expressed as $\mathrm{g} \mathrm{l}^{-1} \mathrm{~h}^{-1}$. Each point and bar indicates the mean $\pm 95 \%$ confidence limits.

during the particular conditions of oxygen concentration that were selected. Only after a minimum of six culture volume changes (typically ten) had occurred between particular conditions was a steady state condition considered to have been achieved. Samples of culture supernatant fluids from steady states were stored at $-20^{\circ} \mathrm{C}$ for later analysis of inorganic phosphate, glucose, $N$-acetylglucosamine and extracellular protein.

The cultures were grown anaerobically under batch culture prior to each continuous culture experiment to minimize the selective pressure for mutants with increased oxygen tolerance.

Statistical analysis. For biomass and extracellular enzyme production data $95 \%$ confidence limits were calculated.

\section{RESULTS}

Maximum specific growth rate, biomass, viable and total counts, extracellular protein and extracellular enzyme production were measured for each species of Propionibacterium grown at steady state with air saturation from 0 to $100 \%$. Steady states were obtained for all three species of cutaneous propionibacteria over the range of 0 to $100 \%$ air saturation.

Maximum specific growth rate. Values of $\mu_{\max }$ obtained by the 'washout' method are shown in Fig. 1. The $\mu_{\max }$ obtained for the anaerobic growth of $P$. acnes was $0.195 \mathrm{~h}^{-1}$, for $P$. avidum $0.195 \mathrm{~h}^{-1}$, and for $P$. granulosum $0 \cdot 120 \mathrm{~h}^{-1}$. These results were in close agreement with those obtained by Greenman et al. (1983) at $\mathrm{pH}$ values $5 \cdot 5$ and 6.0. The presence of oxygen reduced the $\mu_{\max }$ of all three species of propionibacteria. This effect was most apparent with $P$. acnes when the oxygen concentration was increased from 0 to $20 \%$ air saturation. Propionibacterium avidum maintained the highest growth rates in the presence of oxygen. The $\mu_{\max }$ of $P$. granulosum was reduced from $0.082 \mathrm{~h}^{-1}$ to $0.02 \mathrm{~h}^{-1}$ when the oxygen concentration was increased from 80 to $100 \%$ air saturation.

Biomass. Biomass ( $\mathrm{g}^{-1}$ ) increased for all three species between 0 and $20 \%$ air saturation and at $100 \%$ for $P$. granulosum. However, the production rate of biomass assessed as $\mathrm{g} \mathrm{l}^{-1} \mathrm{~h}^{-1}$ showed an overall gradual downward trend between 0 and $100 \%$ air saturation for $P$. granulosum (Fig. 2), a decrease between 0 and $20 \%$ saturation and no further change at higher air saturations for $P$. acnes whilst there was a peak of production at $10 \%$ air saturation for $P$. avidum. 


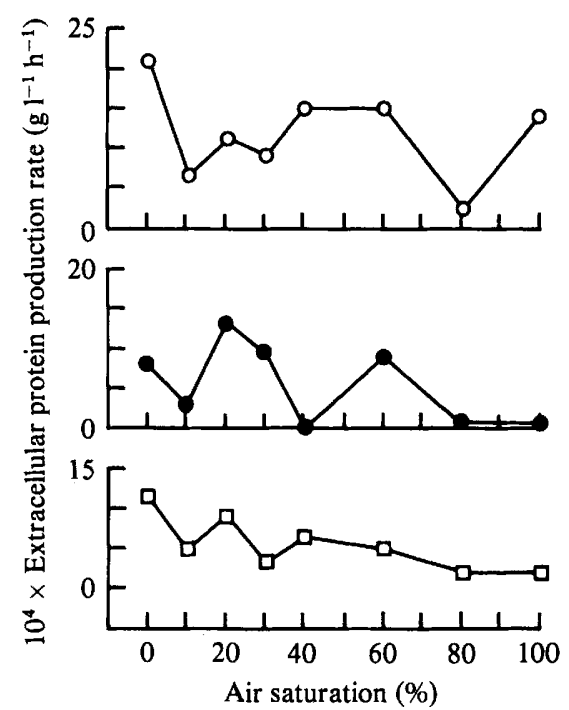

Fig. 3. Effect of oxygen concentration on extracellular protein production rate at $0 \cdot 33 \mu_{\max }$ of $P$. acnes (O), $\boldsymbol{P}$. granulosum (O) and $\boldsymbol{P}$. avidum ( $\square$ ). Each point is the mean of duplicate determinations from a sample of culture supernatant fluid stored at $-20{ }^{\circ} \mathrm{C}$.

Table 2. Denaturation constants for the extracellular enzyme of P. acnes, $P$. avidum and $P$. granulosum determined under anaerobic and aerobic conditions

Denaturation constants were determined by the method of Eaves et al. (1979). Linear regression analysis was used to determine the slopes of the inactivation curves. The gradients obtained for each enzyme under anaerobic and aerobic conditions werre compared using the $F$ test. There was no significant difference $(P>0.05)$ between the values of $\lambda$ obtained anaerobically and aerobically for any of the enzymes.

$\begin{array}{llcc}\text { Organism } & \begin{array}{c}\text { Extracellular } \\ \text { enzyme }\end{array} & \overbrace{\text { Aerobic }} & \text { Denaturation constant } \lambda\left(\mathrm{h}^{-1}\right) \\ P . \text { acnes } & \text { Phosphatase } & -0.08 & -0.12 \\ P . \text { acnes } & \text { Hyaluronate lyase } & -0.04 & -0.04 \\ P . \text { acnes } & \text { Lipase } & -0.18 & -0.08 \\ P . \text { granulosum } & \text { Hyaluronate lyase } & 0 & 0 \\ P . \text { granulosum } & \text { Lipase } & 0 & 0 \\ P . \text { avidum } & \text { Lipase } & -0.15 & -0.13\end{array}$

Total and viable bacterial counts. There was no detectable difference between the total and viable counts of propionibacteria growing at oxygen concentrations from 0 to $100 \%$ air saturation.

Extracellular protein. The method used to measure protein was insensitive to low molecular weight peptides and free amino acids in the tryptone. No detectable protein was found in tryptone using the Bio-Rad assay. These measurements therefore reflected the total extracellular protein production by the bacteria. This varied in all three species with oxygen concentration (Fig. 3). The highest rate of extracellular protein production was achieved by $P$. acnes growing at $0 \%$ air saturation.

Extracellular enzyme production. The stability constants for the propionibacterial extracellular enzymes determined under anaerobic conditions and at $100 \%$ air saturation are given in Table 2 . Linear regression analysis was used to determine the slopes $(\lambda)$ of the inactivation curves. The gradients obtained under anaerobic conditions were compared using the $F$ test. There was no significant difference $(P>0.05)$ between the values of $\lambda$ obtained anaerobically and 


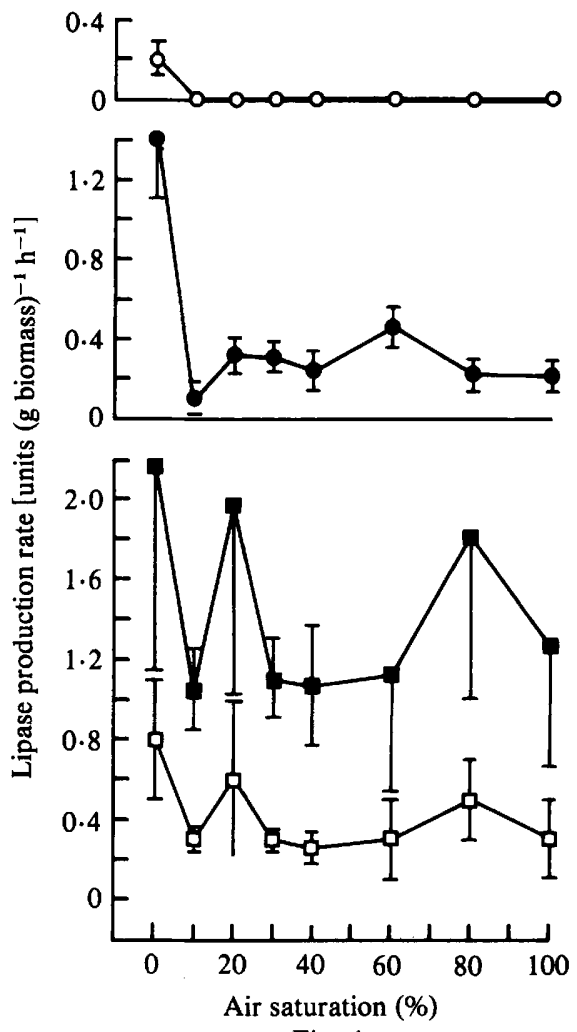

Fig. 4

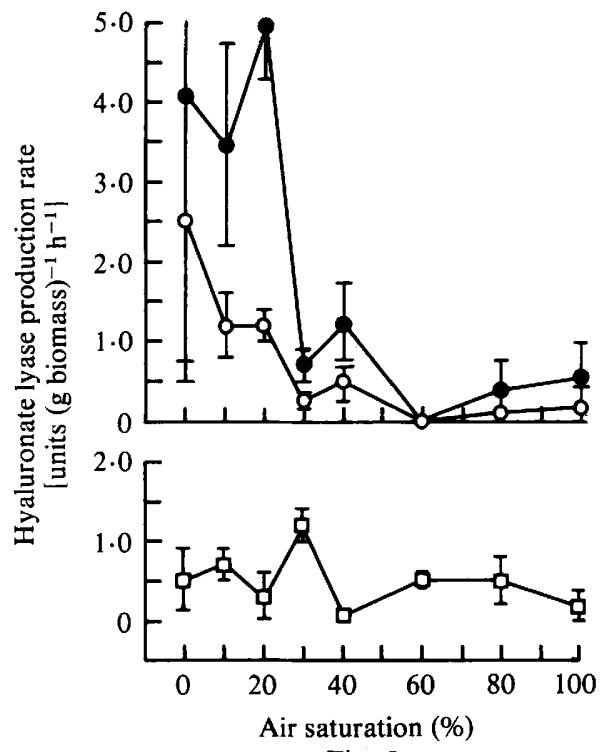

Fig. 5

Fig. 4. Effect of oxygen concentration on production rate of lipase at $0.33 \mu_{\max }$ by $P$. acnes, uncorrected (O), P. granulosum, uncorrected ( () and $P$. avidum, uncorrected $(\square)$ and corrected $(\square)$ for enzyme denaturation. Lipase production rate is expressed as units of enzyme activity (g dry wt cells $)^{-1} \mathrm{~h}^{-1}$. The other details are as in Fig. 2.

Fig. 5. Effect of oxygen concentration on the production rate of hyaluronate lyase at $0.33 \mu_{\max }$ by $P$. acnes uncorrected $(O)$ and corrected $(O)$ and $P$. granulosum $(\square)$ uncorrected for enzyme denaturation. Hyaluronate lyase production rate is expressed as units of enzyme activity (g dry wt cells) $)^{-1} \mathrm{~h}^{-1}$. The other details are as in Fig. 2.

aerobically. It was therefore not considered necessary to determine $\lambda$ for each enzyme at each oxygen concentration tested. The corrected values of extracellular enzyme production rates were calculated using the stability constant $\lambda$ obtained anaerobically.

The results for the corrected and uncorrected production rates for the extracellular enzymes are given in Figs 4 to 6 . The corrected anaerobic production rate of $P$. acnes lipase was $0.2 \pm 0.08$ units (g biomass) $)^{-1} \mathrm{~h}^{-1}$. Values for aerobic production rate of $P$. acnes lipase were not calculated since the levels of enzyme activity obtained were at the limit of detection of the assay, or zero. Corrected $P$. granulosum lipase and hyaluronate lyase production rates are not shown since the value of $\lambda$ was zero for these enzymes. The uncorrected anaerobic production rate of lipase was highest by $P$. granulosum followed by $P$. avidum and $P$. acnes (Fig. 4). These findings were consistent with those of Greenman et al. (1983). The level of lipase production was reduced markedly by $P$. acnes and $P$. granulosum in the presence of oxygen. The corrected and uncorrected production of lipase by $P$. avidum remained constant throughout all the conditions of oxygen tested.

Hyaluronate lyase was produced only by the $P$. acnes and $P$. granulosum strains (Fig. 5). The highest rates of production were obtained at $20 \%$ air saturation for $P$. acnes and at $30 \%$ air saturation for $P$. granulosum. $N$-acetylglucosamine was detected in culture supernatant fluids of $P$. acnes. $N$-acetylglucosamine was not detected in culture supernatant fluids of $P$. granulosum or P. avidum. 


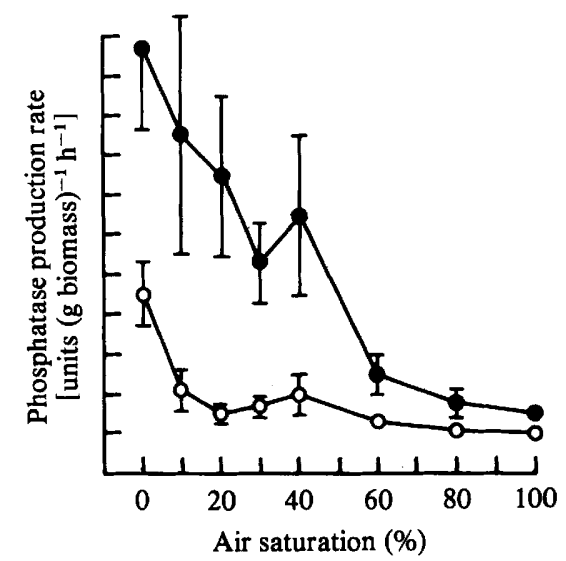

Fig. 6. Effect of oxygen concentration on the production rate of acid phosphatase at $0.33 \mu_{\max }$ by $P$. acnes uncorrected $(O)$, and corrected $(O)$ for enzyme denaturation. Phosphatase production rate is expressed as units of enzyme activity (g dry wt cells) ${ }^{-1} \mathrm{~h}^{-1}$. The other details are as in Fig. 2.

Extracellular acid phosphatase was detected only in the P. acnes strains (Fig. 6). The rate of extracellular acid phosphatase production was reduced at all oxygen concentrations tested (Fig. 6). Analysis of culture supernatant fluids revealed that the growth of all three species. of propionibacteria caused a release of inorganic phosphate into the medium from the tryptonebound phosphate. The level of inorganic phosphate in $P$. acnes cultures appeared to be independent of the activity of extracellular phosphatase.

Corrected values for the production rates of $P$. acnes hyaluronate lyase and phosphatase were obtained which were significantly higher than the uncorrected data. This was apparent particularly at oxygen concentrations less than $40 \%$ air saturation.

Glucose. The glucose, present only in the medium of $P$. granulosum was completely utilized at all the steady states.

\section{DISCUSSION}

Continuous culture provides the most controlled method for determining the effects of environmental change on bacterial growth and product formation. In a tryptone-based medium, increase in glucose concentration up to $3 \%(\mathrm{w} / \mathrm{v})$ increased the biomass of $P$. acnes, $P$. avidum and $\boldsymbol{P}$. granulosum although only $\boldsymbol{P}$. granulosum has a requirement for glucose (Greenman et al., 1981). In the absence of glucose, cultures are, therefore, limited by amino acids supplied by the tryptone which act as both nitrogen and carbon/energy sources (Holland et al., 1979; Greenman et al., 1981). Addition of $0 \cdot 2 \%(\mathrm{w} / \mathrm{v})$ glucose to $P$. granulosum cultures merely spares amino acids that would otherwise be used as carbon/energy sources.

The bacteria were grown anaerobically between steady states to reduce the selection of strains with increased oxygen tolerance. Mutant strains were not detected using the aerobic purity check plates. It is therefore likely that the results obtained represent the phenotypic response of these bacteria to change in oxygen tension.

This study showed that the three species of cutaneous propionibacteria were capable of growth and extracellular enzyme production in the presence of oxygen. Measurements of total and viable counts indicated that oxygen was not lethal to these organisms. This finding was not unexpected since although anaerobiosis is usually required for their isolation and growth, cutaneous propionibacteria do not require anaerobic handling techniques and cultures remain viable when exposed to the atmosphere. 
Propionibacterium avidum was the best adapted of the three species to aerobic environments with respect to growth rate and the production of biomass. Using these criteria, the term microaerophilic may be applied to $P$. avidum. It is interesting that this species is also the most nutritionally adaptable of the cutaneous propionibacteria (Ferguson \& Cummins, 1978; Holland et al., 1979).

The most marked effect of oxygen on the cutaneous propionibacteria was a reduction in the maximum specific growth rate, which may explain the difficulty of isolating these organisms aerobically, since relatively slow growth rates are achieved under optimal conditions anaerobically $\left(0.195 \mathrm{~h}^{-1}\right)$ and 5-7 d are required for their anaerobic isolation. The experiments were carried out at a fixed fraction 0.33 of the maximum specific growth rate of the organism under the conditions imposed. This enabled comparison of the performance of the three species at different percentage air saturation (Tempest, 1976). Since oxygen reduced $\mu_{\max }$, the production rates of cells and extracellular enzymes were consequently affected.

Oxygen did not affect the stability of the propionibacterial extracellular enzymes, but the residence time for each steady state $\left(D=0.33 \mu_{\max }\right)$ was different since $\mu_{\max }$ varied with oxygen concentration. The enzymes were therefore subject to different times of denaturation in the fermenter at different steady states. The derivation of corrected production rates allowed valid comparisons of enzyme production under the different conditions of oxygen concentration.

These results show a general trend of decrease in production of extracellular enzyme with increased air concentration in the environment. Also associated with increased air in the habitat is a decrease in the maximum specific growth rate. Under conditions of slower growth, biomass production rate is lower and in consequence there is a reduced requirement for rate of supply of nutrients. The bacteria in response to slower growth reduce the production rate of exocellular enzymes which are required for the supply of low molecular weight cell membrane transportable nutrients. These originate in the natural environment from high molecular weight polymers or phosphorylated carbon sources. The requirement for high levels of extracellular enzyme production is not necessary with these bacteria because, firstly, these enzymes are stable in the skin environment and, secondly, the environment is composed of solid surfaces and low water content which reduces enzyme dilution and increases efficiency of the enzyme.

The presence of $N$-acetylglucosamine in $P$. acnes cultures requires further investigation. It appears to originate from the $P$. acnes cells, i.e. cell walls or possibly capsular material and not from the medium, since it is not detected in hyaluronidase-producing cultures of $\boldsymbol{P}$. granulosum. The liberation of inorganic phosphate by the growth of cutaneous propionibacteria is probably a result of dephosphorylation of nutrients prior to transport into the cells. The role and regulation of acid phosphatase in $P$. acnes warrants further study.

Further experiments will examine the physiological effects of oxygen on the cutaneous propionibacteria. Oxygen toxicity and the protective measures that bacteria elaborate have been reviewed by Morris (1975). It is well known that cutaneous propionibacteria possess catalase (Marples \& McGinley, 1974), but the presence and regulation of other enzymes such as NADH oxidase and superoxide dismutase have yet to be studied in these bacteria. It is also possible that oxygen is important in the regulation of cytochrome synthesis in cutaneous propionibacteria as has been shown in Propionibacterium shermanii (Pritchard et al., 1977). Roberts (1975) reported that $\boldsymbol{P}$. acnes was capable of oxygen utilization. Studies preliminary to these experiments also showed that cutaneous propionibacteria were capable of reducing the oxygen concentration of their environment. It is not known if this is simply an oxygen detoxifying mechanism or if the cells obtain energetic advantage from the presence of oxygen.

The results of this investigation support the view that changes in extracellular enzyme production altered by propionibacterial growth rate would occur in vivo as a result of a change in the oxygen tension of the pilosebaceous duct or due to exposure of the bacteria at the skin surface. Therefore the oxygen tension in individual follicles may well affect the interaction of the propionibacteria with their environment.

The authors wish to acknowledge the financial support of the Leeds Foundation for Dermatological Research and Vick International Ltd throughout this study. 


\section{REFERENCES}

BRADFORD, M. M. (1976). A rapid and sensitive method for the quantitation of microgram quantities of protein utilizing the principle of protein-dye binding. Analytical Biochemistry 72, 248-254.

Eaves, G., Greenman, J. \& Holland, K. T. (1979). Decay rates of exocellular enzymes produced by bacteria - correction factor of production rates in chemostat cultures. FEMS Microbiology Letters 6, 333-336.

Evans, C. A. \& Mattern, K. (1979). The aerobic growth of Propionibacterium acnes in primary cultures from skin. Journal of Investigative Dermatology 72, 103-106.

Evans, C. A., Smith, W. M., Johnston, E. A. \& GilBERT, E. R. (1950). Bacterial flora of the normal human skin. Journal of Investigative Dermatology 15, 305-324.

Ferguson, D. A. \& Cummins, C. S. (1978). Nutritional requirements of anaerobic coryneforms. Journal of Bacteriology 135, 858-867.

Greenman, J., Holland, K. T. \& Cunliffe, W. J. (1981). Effects of glucose concentration on biomass, maximum specific growth rate and extracellular enzyme production by three species of cutaneous propionibacteria grown in continuous culture. Journal of General Microbiology 127, 371-376.

Greenman, J., Holland, K. T. \& Cunliffe, W. J. (1983). Effects of $\mathrm{pH}$ on biomass, maximum specific growth rate and exoenzyme production by the three species of cutaneous propionibacteria grown in continuous culture. Journal of General Microbiology 129, 1301-1307.

Hastings, G. S. (1971). Partial purification and some properties of lipase from Corynebacterium acnes. Biochemica et biophysica acta 242, 381-394.

Holland, K. T., Cunliffe, W. J. \& Roberts, C. D. (1978). The role of bacteria in acne - a new approach. Clinical and Experimental Dermatology 3, 253-257.

Holland, K. T., Greenman, J. \& Cunliffe, W. J. (1979). Growth of cutaneous propionibacteria on synthetic medium, growth yields and exoenzyme production. Journal of Applied Bacteriology 47, 383394.

InGHaM, E., Holland, K. T., Gowland, G. \& Cunliffe, W. J. (1979). Purification and partial characterisation of hyaluronate lyase (EC 4.2.29.1) from Propionibacterium acnes. Journal of General Microbiology 115, 411-418.

InGHaM, E., Holland, K. T., Gowland, G. \& Cunliffe, W. J. (1980). Purification and partial characterization of an acid phosphatase (EC 3.1.3.2) produced by Propionibacterium acnes. Journal of General Microbiology 118, 59-65.

Ingham, E., Holland, K. T., Gowland, G. \& Cunliffe, W. J. (1981). Partial purification and characterization of lipase (EC 3.1.1.3) from Propionibacterium acnes. Journal of General Microbiology 124, 393-401.

Johnson, J. L. \& Cummins, C. S. (1972). Cell wall composition and deoxyribonucleic acid similarities among the anaerobic coryneforms, classical propionibacteria and strains of Arachnia propionica. Journal of Bacteriology 109, 1047-1066.

Kellum, R. E., Strangfield, K. \& Ray, L. F. (1970). Acne vulgaris. Studies in pathogenesis: triglyceride hydrolysis by Corynebacterium acnes in vitro. Archives of Dermatology 101, 41-47.

MARPles, R. R. \& MCGinley, K. J. (1974). Corynebacterium acnes and other anaerobic diphtheroids from human skin. Journal of Medical Microbiology 7, 349 357.

MCGinley, K. J., Webster, G. F. \& Leyden, J. J. (1978). Regional variations of cutaneous propionibacteria. Applied and Environmental Microbiology 35, 62-66.

Morris, J. G. (1975). The physiology of obligate anaerobiosis. Advances in Microbiological Physiology 12, 169-246.

PIRT, S. J. (1975). Principles of Microbe and Cell Cultivation, Chapter 16. Oxford: Blackwell Scientific Publications.

Pritchard, G. G., Wimpenny, J. W. T., Morris, H. A., LewIS, M. N. A. \& Hughes, D. E. (1977). Effects of oxygen on Propionibacterium shermanii grown in continuous culture. Journal of General Microbiology 102, 223-233.

Puhvel, S. M. \& Reisner, R. M. (1972). The production of hyaluronidase (hyaluronate lyase) by Corynebacterium acnes. Journal of Investigative Dermatology 58, 66-70.

Puhvel, S. M., Reisner, R. M. \& Amiran, D. A. (1975). Quantitation of bacteria in isolated pilosebaceous follicles in normal skin. Journal of Investigative Dermatology 58, 66-70.

Reissig, J. L., Strominger, J. L. \& Leloir, L. F (1955). A modified colorimetric method for the estimation of $\mathrm{N}$-acetylamine sugars. Journal of Biological Chemistry 217, 959-966.

ROBERTS, C. D. (1975). The role of bacteria in Acne vulgaris. Ph.D. thesis. Departments of Microbiology and Dermatology, University of Leeds, U.K.

TEMPEST, D. W. (1970). The continuous cultivation of micro-organisms. 1. Theory of the chemostat. Methods in Microbiology 2, 259-276.

TEMPEST, D. W. (1976). The concept of 'relative' growth rate: its theoretical basis and practical application. In Continuous Culture 6: Applications and New Fields, pp. 349-352. Edited by A. C. R. Dean, D. C. Ellwood, C. G. T. Evans \& J. Melling. Chichester: Ellis Horwood. 